\title{
KESIAPAN SEKOLAH DITINJAU DARI USIA DAN KECERDASAN DI SD MUHAMMADIYAH KABUPATEN ROKAN HULU RIAU
}

\author{
Alucyana $^{1,}$ Ary Antony Putra ${ }^{2}$, Bahril hidayat ${ }^{3}$ \\ ${ }^{1,2,3}$ Fakultas Agama Islam, Universitas Islam Riau, Pekanbaru, Indonesia \\ e-mail:alucyana@fis.uir.ac.id
}

\begin{abstract}
School readiness is essential for children because children ready to enter elementary school will benefit and progress further than those who are not prepared to enter elementary school. Kustimah (2008) stated that the factors that influence children's readiness to enter elementary school include age and level of intelligence. Age factors can affect thinking and work. A person's mindset and grasping power are also influenced by age. The older a person gets, the more his grasping ability and attitude will develop and, of course, affect the knowledge he gains. This study is a quantitative study that aims to determine the effect between age and intelligence of early childhood on their readiness to enter elementary school by using psychological test tools Nijmeegse Schoolbekwaamheids Test (NST) and Colored Progressive Matrices (CPM). This research was conducted at Muhammadiyah Elementary School, Rokan Hulu Regency, Riau Province. From 85 respondents, using the ordinal regression model, the results obtained were 0.998, 0.998, 0.278 and 0.887 ; this shows that age and intelligence have no significant effect on children's readiness to enter school.
\end{abstract}

Keywords: School Readiness, Intelligence, NST, CPM

\begin{abstract}
ABSTRAK
Kesiapan sekolah merupakan hal yang penting bagi anak, karena anak yang telah siap untuk memasuki sekolah dasar akan memperoleh keuntungan dan kemajuan dalam perkembangan selanjutnya dibandingkan anak anak yang belum siap masuk sekolah dasar. Kustimah (2008) menyatakan faktor yang mempengaruhi anak dalam kesiapan masuk sekolah dasar diantaranya adalah usia dan tingkat kecerdasan. Dalam berfikir dan bekerja faktor usia dapat mempengaruhinya. Pola fikir dan daya tangkap seseorang juga dipengaruhi oleh usia di mana semakin bertambah usia seseorang semakin berkembang pula daya tangkap dan pola pikirnya dan tentunya berpengaruh terhadap pengetahuan yang ia peroleh. Penelitian ini merupakan penelitian kuantitatif yang bertujuan untuk mengetahui pengaruh usia dan kecerdasan anak usia dini terhadap kesiapan mereka untuk memasuki Sekolah Dasar dengan menggunakan alat tes psikologi Nijmeegse Schoolbekwaamheids Test (NST) dan Coloured Progressive Matrices (CPM). Penelitian ini dilakukan di Sekolah Dasar Muhammadiyah Kabupaten Rokan Hulu Provinsi Riau. Dari 85 responden, dengan menggunakan model regresi ordinal diperoleh hasil 0,998, 0,998, 0,278 dan 0,887, hal ini menujukkan bahwausia dan kecerdasan tidak berpengaruh signifikan terhadap kesiapan anak masuk sekolah.
\end{abstract}

Kata kunci: Kesiapan Masuk Sekolah, Kecerdasan, NST, CPM

157

Alucyana, Ary Antony Putra, Bahril hidayat Kesiapan Sekolah Ditinjau dari Usia dan Kecerdasan di SD Muhammadiyah Kabupaten Rokan Hulu Riau 


\begin{tabular}{c|c|c|c}
\hline FIRST RECEIVED: & REVISED: & ACCEPTED: & PUBLISHED: \\
23 August 2021 & 28 October 2021 & 30 October 2021 & 31 October 2021
\end{tabular}

\section{PENDAHULUAN}

Anak adalah miniaturnya manusia dewasa, dimana mereka sejak lahir telah Allah berikan potensi, maka lingkungan yang berperan besar dalam mengembangkan potensi yang mereka miliki tersebut. Anak yang berusia 0-6 tahun disebut anak usia dini, usia ini juga dikenal dengan masa golden age yang disebut masa keemasan. Pada masa inilah berkembangnya seluruh potensipotensi pada anak usia dini, baik aspek kognitif, bahasa, perkembangan motorik dan aspek sosial dan emosional. Usia ini juga otak mereka berkembang demikian pesatnya. Oleh karena itu, pada masa ini mempermudah bagi orangtua dan guru menginternalisasikan pengetahuan kepada mereka, dalam mengenalkan bentuk konsep maupun dalam bentuk aktualisasi dalam kehidupan sehari hari. Jika di usia ini pendidikan diberikan secara optimal serta rangsangan yang tepat maka akan sangat baik untuk perkembangan di usia selanjutnya. (Peraturan Mentri Pendidikan dan Kebudayaan nomor 146 Tahun 2014 tentang kurikulum tahun 2013 PAUD)

Masa krusial belajar anak dimulai dari dalam kandungan hingga seribu hari pertama di masa kehidupannya. Pakar syaraf mengatakan, saat lahir otak bayi mengandung seratus hingga dua ratus milyar neuron, di mana sel syaraf tersebut akan melakukan sambungan antar sel. Sebaliknya jika anak dibesarkan dengan satu kekerasan maka akan dapat merusak 1 sampai 10 milyar sel otak. Karenanya, upaya yang bisa diperbuat untuk pengembangan potensi anak usia dini tersebut salah satunya dengan program Pendidikan terstruktur yakni melalui Lembaga PAUD (Peraturan Mentri Pendidikan dan Kebudayaan nomor 146 Tahun 2014 tentang kurikulum tahun 2013 PAUD). Sujiono dalam Alucyana (2017) juga mengatakan masa golden age ini hanya terjadi sekali dalam perkembangan manusia, oleh sebab itu masa ini disebut masa yang krusial dalam kehidupan. Di masa keemasan ini anak usia dini sedang menjalani kehidupan yang sangat fundamental untuk perkembangan selanjutnya. Jika masa ini terjadi pengabaian baik pengasuhan, pendidikan, perawatan, dan kesehatan maka tumbuh kembang anak tidaklah berjalan sesuai dengan perkembangannya. Oleh sebab itu pihak terkait hendaknya mengetahui pentingnya masa usia dini tersebut serta mengetahui bagaimana mengoptimalisasi pertumbuhan dan perkembangannya (Yamin Martinis \& Jamilah Sabri Sanan, 2013).

Mc Carthy dan Houston, (1980) telah merintis pendidikan anak usia dini sejak abad ke 18. Para ahli telah menyepakati bahwa pendidikan di masa usia dini sangatlah penting. Seberapa besar stimulasi yang diberikan pada anak di masa tersebut akan menentukan perkembangan selanjutnya. Pandangan psikologi juga berpendapat demikian yang dikenal dengan istilah rentang 
kehidupan (life-span perspective) yang menyebutkan bahwa perkembangan manusia memiliki hubungan yang kuat antar perkembangan satu dengan perkembangan lainnya. Artinya Ketika tahap perkembangan pada tahap satu berjalan dengan baik maka akan mempengaruhi tahap perkembangan berikutnya, masa usia dini merupakan peletakan dasar untuk keberhasilan pada jenjang studi berikutnya. Di usia inilah momentum yang tepat untuk meletakkan pondasi dasar perkembangan baik aspek fisik, sosial, kognitif, konsep diri, seni dan moral. Agar masa tersebut berkembang secara optimal maka perlu secara menyeluruh memperhatian aspek yang mencakup seluruh dasar kehidupan manusia baik fisik maupun perkembangan mental (Mukhtar Latif, dkk, 2013).

Seperti yang telah disebutkan sebelumnya, perkembangan kognitif merupakah bagian dari aspek yang dikembangan pada usia dini. Aspek kognitif merupakan salah satu aspek yang ada pada manusia yang meliputi tentang pengertian (pengetahuan), dimana pada aspek tersebut terjadi proses berfikir yang terlihat dalam kemampuan manusia dalam membuat penilaian, menghubungkan satu peristiwa dengan peristiwa lainnya dan ditarik kesimpulan. Kemampuan nalar, kreatifitas atau kemampuan menciptakan sesuatu, daya ingat serta kemampuan berbahasa merupakan pengertian dari kognitif itu sendiri. Penggabungan kematangan anak dan lingkungan dinamai kognisi (Khadijah, 2016). Dalam pengukuran psikologi, intelekual dapat diukur dengan alat test psikologi. Salah satu alat tes alat tes psikologi yang dapat mengukur taraf kecerdasan anak usia 5-11 tahun adalah Colour Progresive Matric (CPM).

Berdasarkan wawancara awal kepada kepala sekolah dan guru di SD Muhammadiyah Kabupaten Rokan Hulu Provinsi Riau, menyatakan bahwa jika mereka hanya menerima calon peserta didik berdasarkan observasi dan wawancara saja, mereka kurang mendapatkan hasil yang akurat. Mereka tidak mengetahui tingkat kecerdasan anak serta apakah mereka sudah siap masuk sekolah dasar, karena secara pengamatan sederhana mereka anak anak tersebut berkembang dengan baik namun belum memasuki usia 7 tahun. Pengalaman sebelumnya guru menjadi kewalahan dalam proses belajar dan mengajar terhadap siswa, karena ternyata mereka tidak siap untuk masuk sekolah dasar. Terlihat beberapa anak yang belum memahami instruksi tugas, konsentrasi yang masih rendah, aspek sosial yang belum berkembang baik serta belum siapnya mereka menerima tuntutan tugas yang lebih berat di sekolah dasar. Sementara guru juga dihadapkan pada pernyataan calon wali murid peserta didik yang mengatakan bahwa anak-anak mereka sudah bisa membaca, menulis dan berhitung. Menurut Edia (2012), Sebelum anak masuk sekolah ada dua hal yeng perlu menjadi perhatian yaitu : kematangan masuk sekolah dan kesiapan anak masuk sekolah. Adapun yang dimaksud dengan kesiapan anak masuk sekolah dasar adalah ketrampilan akademik yang dimiliki anak yang diperlukan saat mereka mengerjakan tugas tugas yang

Alucyana, Ary Antony Putra, Bahril hidayat Kesiapan Sekolah Ditinjau dari Usia dan Kecerdasan di SD Muhammadiyah Kabupaten Rokan Hulu Riau 
menjadi tuntutan di sekolah dasar (usia 6-7 tahun di awal pendidikan dasar) (Mariyati dan Afandi, 2016). Dalam pengukuran psikologi alat test yang dapat melihat kesiapan atau kematangan masuk sekolah dasar adalah alat test NST. Alat test tersebut dapat memprediksi kesiapan anak masuk sekolah dasar. Beberapa penelitian telah dilakukan untuk melihat faktor apa saja yang mempengaruhi anak masuk sekolah dasar. Penelitian oleh Dewi Sartika, Lilim Halimah, Nurul Annisa (2011) dengan judul Studi Eksplorasi Mengenai Kesiapan Anak Masuk Sekolah Dasar Ditinjau dari Hasil Tes NST di PAUD Cihanjuang dan PAUD Cikutra Indah Bandung. Hasil penelitian menggambarkan bahwa PAUD Cihanjuang ada $50 \%$ yang siap untuk sekolah dan $50 \%$ yang tidak siap sekolah. Sedangkan pada PAUD Cikutra 71 $\%$ yang siap untuk sekolah dan $29 \%$ yang tidak siap sekolah. Pada penelitian lain dilakukan oleh Nur Halimah dan Fajar Kawuryan (2010) yang berjudul Kesiapan Memasuki Sekolah Dasar pada Anak yang mengikuti Pendidikan TK dengan yang tidak mengikuti Pendidikan TK di Kabupaten Kudus. Hasil penelitiannya menunjukkan bahwa terdapat perbedaan yang sangat signifikan kesiapan sekolah antara anak yang mengikuti pendidikan TK $($ Mean $=25,98)$ dengan yang tidak mengikuti pendidikan TK (Mean $=11,25)$, dimana anak SD yang sebelumnya mengikuti pendidikan TK memiliki kesiapan sekolah lebih tinggi dibandingkan yang tidak mengikuti pendidikan TK. Nuryati Mustamiroh (2012) juga melakukan penelitian yang berjudul Kesiapan Bersekolah Anak pada Anak-anak
TK Fullday Ditinjau dari Tingkat Pendidikan Orang Tua. Hasil analisis penelitian tersebut menggambarkan bahwa ada perbedaan yang signifikan kesiapan bersekolah anak yang memiliki orang tua yang berpendidikan sekolah menengah dan perguruan tinggi dan kesiapan anak memasuki SD pada orang tua dengan pendidikan PT memiliki kategori sedang dan kesiapan anak memasuki SD pada orang tua dengan pendidikan PT memiliki kategori rendah.

Dari pemaparan di atas peneliti menyimpulkan penting dilakukan penelitian untuk melihat kesiapan masuk sekolah ditinjau dari usia dan taraf kecerdasan. Adapun yang menjadi rumusan masalah dalam penelitian ini adalah: Apakah ada pengaruh Usia terhadap kesiapan masuk sekolah dasar dan apakah ada pengaruh Tingkat kecerdasan (IQ) terhadap kesiapan masuk sekolah dasar?

\section{METODE PENELITIAN}

Jenis penelitian ini merupakan penelitian korelasional yang menggunakan pendekatan kuantitatif yang mana data berupa angka untuk kemudian dihitung dan dianalisa menggunakan analisa statistik. Penelitian ini dilakukan di SD MUHAMMADIYAH Kabupaten Rokan Hulu Propinsi Riau. Penelitian ini dilakukan selama 8 bulan yakni mulai dari bulan April - November 2020. Metode pengumpulan data yang utama digunakan dalam penelitian ini dengan cara pengetesan kepada anak dengan menggunakan alat tes NST. Tes NST merupakan alattes yang bertujuan untuk mengukur kesiapan anak masuk sekolah 
dasar, dengan melihat kesiapan fisik (psikomotor), intelektual, emosi dan sosial. Tes ini menghasilkan skor yang membutuhkan interpretasi dari psikolog, sehingga menghasilkan profil kesiapan anak masuk sekolah.

Populasi dalam penelitian ini adalah siswa-siswi yang mengikuti pendidikan Taman Kanak-kanak atau lembaga PAUD dan calon siswa/siswi yang akan melanjutkan ke sekolah dasar di daerah Rokan Hulu. Sampel yang digunakan dalam penelitian ini adalah calon siswa di SD Muhammadiyah yang berjumlah 85 orang, dengan kriteria yaitu: 1) Anak-anak kelompok TK B. 2) Telah terdaftar di SD Muhammadiyah Rambah, Rokan Hulu. 3) Usia diantara 5,10 tahun -7 tahun

Variable penelitian ini terdiri dari Variabel Bebas: Usia dan Kecerdasan (IQ) serta Variabel Terikat: Kesiapan Masuk Sekolah Dasar. Sedangkan analisis data dalam penelitian ini menggunakan Korelasi Rank Spearman digunakan untuk mencari korelasi antara 2 variabel yang memiliki skala ordinal yang memungkinkan untuk diberi jenjang. Data yang digunakan dapat bersumber dari sumber yang berbeda dan tidak harus berdistribusi normal. Teknik statistika ini merupakan kelompok statistika nonparametric. Analisis penelitian ini memakai model analisis regresi ordinal dengan data berskala ordinal. Model ini digunakan untuk mendapatkan gambaran sederhana tentang pengaruh variable bebas terhadap variable terikat

\section{HASIL DAN PEMBAHASAN}

\section{Karakteristik Responden}

Dari hasil olah data terhadap 85 orang calon siswa SD Muhammadiyah Rokan Hulu, terdapat 20 anak yang beusia kurang dari 6 tahun atau sebanyak $23,3 \%$ dari total peserta tes, 39 anak berusia 6 sampai 6,5 tahun atau sebesar $45,9 \%$ dan 26 anak berusia di atas 6,5 tahun atau $30,6 \%$.

Tabel 4.1

Usia Anak

\begin{tabular}{|l|c|c|}
\hline \multicolumn{1}{|c|}{ Usia } & Frequency & Percent \\
\hline$<6$ tahun & 20 & 23.5 \\
$6-6,5$ tahun & 39 & 45.9 \\
$>6,5$ tahun & 26 & 30.6 \\
Total & 85 & 100.0 \\
\hline
\end{tabular}

Penelitian ini menggunakan kategori taraf kecerdasan CPM dari Raven yang hasil berupa kategori kecerdasan, yaitu superior, di atas rata-rata, rata-rata dan di bawah ratarata. Dibawah ini merupakan tabel jumlah siswa berdasarkan kategori tersebut, dimana anak yang berada pada taraf kecerdasan superior berjumlah 11 orang atau sebesar $12,9 \%$ dari total jumlah peserta, anak yang berada di atas rata-rata berjumlah 26 orang atau $30,6 \%$, anak yang bertaraf kecerdasan rata-rata berjumlah 33 orang atau sebanyak $38,8 \%$ dan di bawah rata-rata sebanyak 15 orang atau sebesar $17,6 \%$

Tabel 4.2

Kategori Taraf Kecerdasan

\begin{tabular}{|l|c|c|}
\hline & Frequency & Percent \\
\hline Superior & 11 & 12.9 \\
Di Atas Rata-Rata & 26 & 30.6 \\
Rata-Rata & 33 & 38.8 \\
Di Bawah Rata-Rata & 15 & 17.6 \\
Total & 85 & 100.0 \\
\hline
\end{tabular}

161

Alucyana, Ary Antony Putra, Bahril hidayat Kesiapan Sekolah Ditinjau dari Usia dan Kecerdasan di SD Muhammadiyah Kabupaten Rokan Hulu Riau 
Kesiapan masuk sekolah dapat diukur dengan instrument piskologi salah satunya

Tabel 4.4

Correlations

\begin{tabular}{|ll|r|r|r|}
\hline & & Rekomen & Usia & \multicolumn{1}{c|}{ IQ } \\
\hline \multirow{4}{*}{ Rekomendasi } & Correlation & 1.000 & -.094 & $.333^{*}$ \\
& Coefficient & & & $*$ \\
& Sig. (2-tailed) &. & .393 & .002 \\
& $\mathrm{~N}$ & 85 & 85 & 85 \\
& Correlation & -.094 & 1.000 & .147 \\
& Coefficient & & & \\
Usia & Sig. (2-tailed) & .393 &. & .178 \\
& N & 85 & 85 & 85 \\
& Correlation & $.333^{* *}$ & .147 & 1.000 \\
& Coefficient & & & \\
Sig. (2-tailed) & .002 & .178 &. \\
& N & 85 & 85 & 85 \\
\hline
\end{tabular}

**. Correlation is significant at the 0.01 level (2-tailed).

dengan tes NST. Hasil dari tes NST berupa rekomendasi disarankan, dipertimbangkan dan tidak disarankan. Pada penelitian ini terdapat 4 anak yang mendapat rekomendasi dipertimbangkan atau sebesar 4,7\%, 81 anak disarankan atau 95,3\% dan tidak ada anak yang mendapat rekomendasi tidak disarankan.

Tabel 4.3

Rekomendasi

\begin{tabular}{|l|c|c|}
\hline & Frequency & Percent \\
\hline DIPERTIMBANGKAN & 4 & 4.7 \\
DISARANKAN & 81 & 95.3 \\
Total & 85 & 100.0 \\
\hline
\end{tabular}

\section{Hasil Uji Rank Spearman}

Korelasi Rank Spearman digunakan untuk mencari hubungan antara 2 variabel yang masing-masing datanya berskala ordinal sehingga dapat diberi jenjang, data variable yang ingin di korelasikan dapat berasal dari sumber yang tidak sama dan juga tidak terdistribusi normal. Uji hipotesis dengan membandingkan sig.(2-tailed) dengan $\alpha(0,05)$. Jika nilaisig.(2-tailed) $\geq \alpha$ $(0,05)$ maka $\mathrm{H}_{0}$ diterima dan $\mathrm{H}_{\mathrm{a}}$ ditolak. Sebaliknya jika nilai sig.(2-tailed $)<\alpha(0,05)$ maka $\mathrm{H}_{0}$ ditolak dan $\mathrm{H}_{\mathrm{a}}$ diterima.Nilaicorrelation coefficient, dapat menentukan arah korelasi. Hubungan yang searah dapat di lihat dengan nilai correlation coefficient yang positif namun hubungan tidak searah. Ditentukan oleh nilai correlation coefficient negative. Berikut tabel hasil uji rank spearman.

Berdasarkan tabel di atas menunjukkan hasil uji korelasi rank spearman antara variabel kesiapan masuk sekolah/ rekomendasi hasil NST (Y) dengan variabel usia (X1), didapat 3 nilai yaitu -0,094, 0,393 dan 85 . Nilai 85 menunjukkan jumlah sampel yaitu sebanyak 85 responden. Nilai -0,094 menunjukkan korelasi yang sangat lemah antara variabel rekomendasi dan usia. Nilai 0,393 menunjukkan bahwa antara variabel rekomendasi dan usia tidak memiliki hubungan yang berarti.

Sedangkan untuk korelasi antara rekomendasi (Y) dengan IQ (X2) didapat nilai $0.333,0,002$ dan 85 . Nilai 85 menunjukkan jumlah sampel yaitu sebanyak 85 responden. Nilai 0,333 menunjukkan hubungan yang cukup kuat antara variabel rekomendasi dan IQ. Nilai 0,002 menunjukkan bahwa antara variabel rekomendasi dan IQ memiliki hubungan yang signifikan. 


\section{Hasil Uji Regresi Ordinal}

Variable dengan skala pengukuran minimal ordinal maka analisisnya menggunakan analisis regresi ordinal, agar memperoleh gambaran pengaruh antara variable bebas dengan variable terikat. Demikian pula dalam penelitian ini, tujuan menggunakan analisis regresi ordinal untuk membuktikan hipotesis tentang pengaruh varibael usia (X1) dan IQ (X2) terhdapa kesiapan masuk sekolah (Y). Berikut output pengujian regresi ordinal menggunakan SPSS 21.

Tabel 4.5

Model Fitting Information

\begin{tabular}{|l|r|c|c|c|}
\hline Model & $\begin{array}{c}-2 \text { Log } \\
\text { Likelihoo } \\
\mathrm{d}\end{array}$ & $\begin{array}{c}\text { Chi- } \\
\text { Square }\end{array}$ & $\mathrm{df}$ & Sig. \\
\hline Intercept Only & $\begin{array}{r}21.874 \\
5.570\end{array}$ & 16.304 & 5 & .006 \\
\hline
\end{tabular}

Link function: Logit.

Untuk mengetahui signifikan atau tidaknya model regresi ordinal maka digunakan Model fitting information. -2log likelihood menjelaskanbahwa tanpa memasukkan variabel independen (intercept only) nilainya 21,874 , setelah memasukkan variabel independen ke model (final) terjadi penurunan nilai menjadi 5,570. Perubahan nilai ini ditunjukkan dengan nilai chi-square, yaitu 16,304. -2log likelihood merupakan tingkat kecocokan model yang dianalisis, yang mana apabila modelFinal memiliki pengaruh (nilaisig. $\leq 0,05$ ), maka terdapat peningkatan nilai yang signifikan atas model Intercept Only.Dari table di atas, diperoleh nilai sig. sebesar 0,006, yang artinya model tersebut dinyatakan bahwa terdapat pengaruh antara variable IQ dan usia terhadap kesiapan masuk sekolah.

Tabel 4.6

Goodness-of-Fit

\begin{tabular}{|l|r|r|r|}
\hline & Chi-Square & \multicolumn{1}{c|}{$\mathrm{df}$} & \multicolumn{1}{c|}{ Sig. } \\
\hline Pearson & .000 & 6 & 1.000 \\
Deviance & .000 & 6 & 1.000 \\
\hline
\end{tabular}

Link function: Logit.

Untuk menguji kesesuaian model regresi ordinal dengan data empiris yang diteliti digunakan Goodness of fit. Tabel di atasmenunjukkan nilai Pearson Chi-Square sebesar 0.00 dengan signifikansi $1>0,05$ dan juga Deviance sebesar 0.00 dengan signikansi $1>0,05$, yang artinya data konsisten dan layak di uji.

Tabel 4.7

Pseudo R-Square

\begin{tabular}{|l|r|}
\hline Cox and Snell & .175 \\
Nagelkerke & .553 \\
McFadden & .505 \\
\hline
\end{tabular}

Link function: Logit.

Pseudo R-Square digunakan untuk mengetahui seberapa besar variabel independen (IQ dan usia)dapat menjelaskan variabel dependen (kesiapan masuk sekolah). Berdasarkan tabel diatas diperoleh beberapa nilai $R$ square, diantaranya Nilai Cox and Snell sebesar 0,175 (17,5\%), Nagelkerke sebesar 0,553 (55,3\%), dan Nilai Mc Faden sebesar 0.505 (50,5\%). Masing-masing dari tersebut berarti bahwa variable bebas mempengaruhi variabel terikat sebesar 17,5\% (Cox and Snell), sedangkan sisanya $82,5 \%$ dipengaruhi oleh factor lain yang tidak masuk dalam penelitian. Sama halnya dengan nilai Nagelkerke $(0,553)$ yang berarti bahwa

Alucyana, Ary Antony Putra, Bahril hidayat Kesiapan Sekolah Ditinjau dari Usia dan Kecerdasan di SD Muhammadiyah Kabupaten Rokan Hulu Riau 
variable bebas memberikan pengaruh kepada variable terikat sebesar $55,3 \%$ sedangkan $44,7 \%$ lagi adalah factor lain yang tidak diuji. Begitu juga dengan nilai Mc Faden (0.505), yang artinya variable bebas berpengaruh sebesar $50,5 \%$ pada variable terikat.

Tabel 4.8

Parameter Estimates

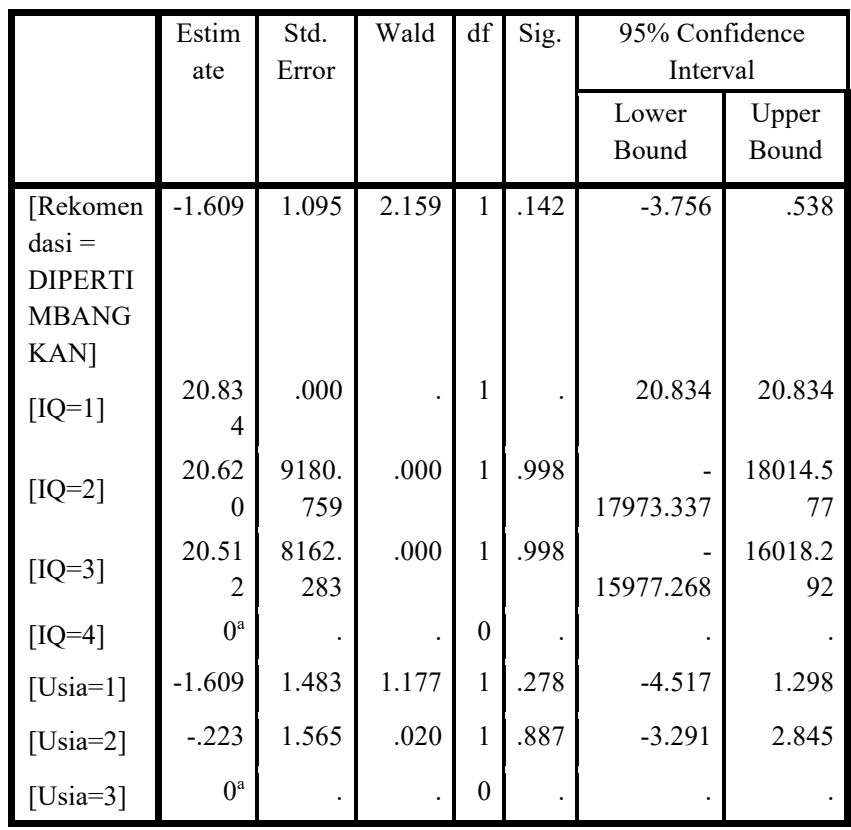

Link function: Logit.

a. This parameter is set to zero because it is redundant.

Parameter estimates melihat signifikansi pengaruhmasing-masing variable bebas terhadap variable terikat, yang apabila pada nilai sig. $<0,05$ maka dinyatakan signifikan. Dari table di atas xmenunjukkan semua variable bebas memiliki nilai signifkansi $>0,05$, yaitu 0,998 (IQ di atas rata-rata), 0,998 (IQ rata-rata), 0,278 (di bawah 6 tahun) dan 0,887 (6-6,5 tahun) yang mana artinya variable bebas (IQ dan usia) tidak berpengaruh signifikan pada variable terikat (kesiapan masuk sekolah).
Kustimah (2008) menyatakan faktor yang mempengaruhi anak dalam kesiapan masuk sekolah dasar diantaranya adalah usia dan tingkat kecerdasan. Menurut Uno (2010) Kecerdasan intelektual merupakan gambaran bagaimana sesorang dalam menghadapi lingkungannya secara efektif. Dalam berfikir dan bekerja faktor usia dapat mempengaruhinya. Pola fikir dan daya tangkap seseorang juga dipengaruhi oleh usia di mana semakin bertambah usia seseorang semakin berkembang pula daya tangkap dan pola pikirnya dan tentunya berpengaruh terhadap pengetahuan yang ia peroleh. Namun berbeda dengan pernyataan di atas, hasil penelitian kali ini menunjukkan bahwa usia dan tingkat kecerdasan anak tidak berpengaruh signifikan pada kesiapan masuk sekolah dasar.

\section{SIMPULAN}

Hasil penelitian ini menyimpulkan bahwa usia dan tingkat kecerdasan (IQ) tidak berpengaruh signifikan terhadap kesiapan anak masuk sekolah dasar.

Hasil penelitian dapat menjadi masukan bagi orang tua dan guru untuk mempersiapkan aspek aspek perkembangan untuk kesiapan anak masuk sekolah dasar. Penelitian ini juga dapat dikembangkan dengan vaiabel yang lain atau aspek yang lain dari hasil NST untu dikaitkan dengan perkembangan anak usia dini.

\section{DAFTAR PUSTAKA}

Alucyana. (2017). Pengembangan Potensi Anak Usia Dini. IAIN Pontianak Press. 
Damayanti, Kusuma, A., \& Rachmawati. (2016). Kesiapan Anak Masuk Sekolah Dasar Ditinjau dari Dukungan Orang Tua dan Motivasi Belajar. Jurnal Psikovidya .

Halimah, Nur, \& Kawuryan, F. (2010). Kesiapan Memasuki Sekolah Dasar pada Anak yang Mengikuti Pendidikan TK dengan yang Tidak Mengikuti Pendidikan TK di Kabupaten Kudus. Jurnal Psikologi Universitas Muria Kudus .

Huberman, A. M., \& Mile, M. B. (1992). Analisis Data Kualitatif. Jakarta: Universitas Indonesia.

Hurlock, E. B. (1998). Psikologi Perkembangan. Jakarta: Erlangga.

Khadijah. (2016). Pengembangan Kognitif Anak Usia Dini. Perdana Publishing .

Kustimah, Kusumawati, D., \& A. F. (2008). Gambaran Kesiapan Anak Masuk Sekolah Dasar Ditinjau Dari Hasil NST. Jurnal Psikologi .

Latif, M., Zukhairina, Zubaidah, R., \& Affandi, M. (2013). Orientasi Baru Pendidikan Anak Usia Dini. Jakarta: Kencana.

Mustamiroh, N. (2012). Kesiapan Bersekolah Anak pada Anak-anak TK Fullday Ditinjau dari Tingkat Pendidikan Orang Tua. Naskh Publikasi .

Novitawati. (2011). Kesiapan Sekolah Anak Taman Kanak-kanak Berbasis Model Pembelajaran Sentra (Studi Kualitatif di TK Islam Sabilal Muhtadin Banjarmasin. Jurnal Pendidikan Anak Usia Dini .
Santrock, J. (1995). Life Span Development. Jakarta: Erlangga.

Sartika，D., Halimah, L., \& Annisa, N. (2011). Studi Eksplorasi Mengenai Kesiapan Anak Masuk Sekolah Dasar Ditinjau dari Hasil Tes NST di PAUD Cihanjuang dan PAUD Cikutra Indah Bandung. Prosiding Seminar Nasional Penelitian dan PKM: Sosial, Ekonomi dan Humaniora .

Sugiyono. (2013). Statistika Untuk Penelitian. Jakarta: Alfabeta.

Sujanto, A. (2012). Psikologi Umum. Jakarta: PT. Rineka Cipta.

U. B., Hamzah, \& Kuadrat, M. (2010). Mengelola Kecerdasan dalam Pembelajaran. Jakarta: Bumi Aksara.

Yamin Martinis, J. S. (2013). Panduan. Gaung Persada Press Group.

Yenti, K. N. (2014). Pengaruh Kecerdasan Emosional, Kecerdasan Intelektual dan Disiplin Terhadap Kinerja Perawat pada R.S PMC Pekanbaru. Journal Onlinr Mahasiswa Fakultas Ekonomi Universitas Riau.

Alucyana, Ary Antony Putra, Bahril hidayat Kesiapan Sekolah Ditinjau dari Usia dan Kecerdasan di SD Muhammadiyah Kabupaten Rokan Hulu Riau 